RESEARCH ARTICLE

\title{
Ecological biogeography of mangroves in Sri Lanka
}

\author{
M.D. Amarasinghe ${ }^{1, *}$ and K.A.R.S. Perera ${ }^{2}$ \\ ${ }^{1}$ Department of Botany, University of Kelaniya, Kelaniya \\ ${ }^{2}$ Department of Botany, The Open University of Sri Lanka, Nawala, Nugegoda
}

Received: 10/01/2017; Accepted: 10/08/2017

\begin{abstract}
The relatively low extent of mangroves in Sri Lanka supports 23 true mangrove plant species. In the last few decades, more plant species that naturally occur in terrestrial and freshwater habitats are observed in mangrove areas in Sri Lanka. Increasing freshwater input to estuaries and lagoons through upstream irrigation works and altered rainfall regimes appear to have changed their species composition and distribution. This will alter the vegetation structure, processes and functions of mangrove ecosystems in Sri Lanka. The geographical distribution of mangrove plant taxa in the micro-tidal coastal areas of Sri Lanka is investigated to have an insight into the climatic and anthropogenic factors that can potentially influence the ecological biogeography of mangroves and sustainability of these mangrove ecosystems.
\end{abstract}

Keywords: mangrove ecosystems, micro-tidal habitats, ecological biogeography, Sri Lanka.

\section{INTRODUCTION}

Interactions between organisms and their environment, both abiotic and biotic, are crucial in determining their current spatial distribution on the planet. Ecological biogeography essentially is a study on factors affecting distribution of species (Monge-Najera, 2008). Mangrove plants being endemic to inter-tidal areas are largely affected by factors such as climate, salinity and hydrology, apart from anthropogenic influences on habitat quality and availability. The objective of this study was to have an insight into the potential factors, both natural and anthropogenic that determine biogeography of mangrove plant species in Sri Lanka. In this respect, exclusivity of true mangrove species to inter-tidal zone provides a surrogate to study change in the mangrove environment, as exclusivity represents the extent to which these species are adapted to the inter-tidal environment and therefore their ability to perform ecological functions in this harsh environment. A study on leaf structural traits and osmotic properties of plants in mangrove areas reveals that true mangroves are the true halophytes and mangrove associates are glycophytes with certain salt tolerance (Wang et al., 2010). Moreover, presence of non-exclusive species (mangrove associates) in the typical mangrove habitats indicates change, especially of salinity and inundation regimes. This emphasizes the importance of identification of plants as true and associate species. Generally this classification is based on observations on the occurrence of species within and outside the inter-tidal zones and it largely rests on how extensively the observations are made and how reliable the identification of plants is, thus, rendering a considerable element of subjectivity. An attempt to reduce subjectivity in this respect is presented in the paper on "Historical biogeography of mangroves in Sri Lanka" in this volume.

\section{MATERIALS AND METHODS}

Literature on mangrove distribution in Sri Lanka was collated to analyze the gaps in knowledge on distribution/ occurrence of true mangrove species. Recently published information on mangrove distribution on the northern and eastern coasts could not be found, most probably for the reason that these areas were inaccessible until the near past. In order to study the current status of species richness and diversity, major mangrove areas on all four coasts, especially those on the northern and eastern coasts were studied during $2010-2013$. The study areas included Thondaimannar lagoon, Nayaru lagoon, Yan Oya estuary, Uppar lagoon, Batticaloa lagoon, Urani and Pottuvil lagoons, Rekawa lagoon, Negombo lagoon, Chilaw lagoon, Kala Oya and Malwathu Oya estuaries (Figure 1). Although in-depth studies were not conducted, mangrove areas around Mannar and Palk Bay (Viduthalathivu) were also visited to record species richness.

Species richness and density data were collected from $10 \mathrm{~m}$-wide belt transects laid perpendicular to the shoreline (6-12 transects per study area depending on the area of the mangrove stand) across the water-land gradient. All plants with girth more than $2.5 \mathrm{~cm}$ were identified and enumerated. Literature on the regional mangrove distribution, especially in south and southeast Asia as well as in East Africa were also examined.

\section{RESULTS AND DISCUSSION}

\section{Biogeography of mangroves of Sri Lanka}

The relative abundance of mangrove species in each mangrove area is presented in pie diagrams included in Figure 1. Except in the Yan oya estuary, mangrove areas on the dry northern and eastern coasts support less number of mangrove species than on the southern and western coasts. Although the extent of mangrove areas left on the wetter western and southern coasts is relatively low, they accommodate the highest number of mangrove species (Figure 1). The mangrove stands in Chilaw lagoon located in the intermediate climatic zone on the west coast however 


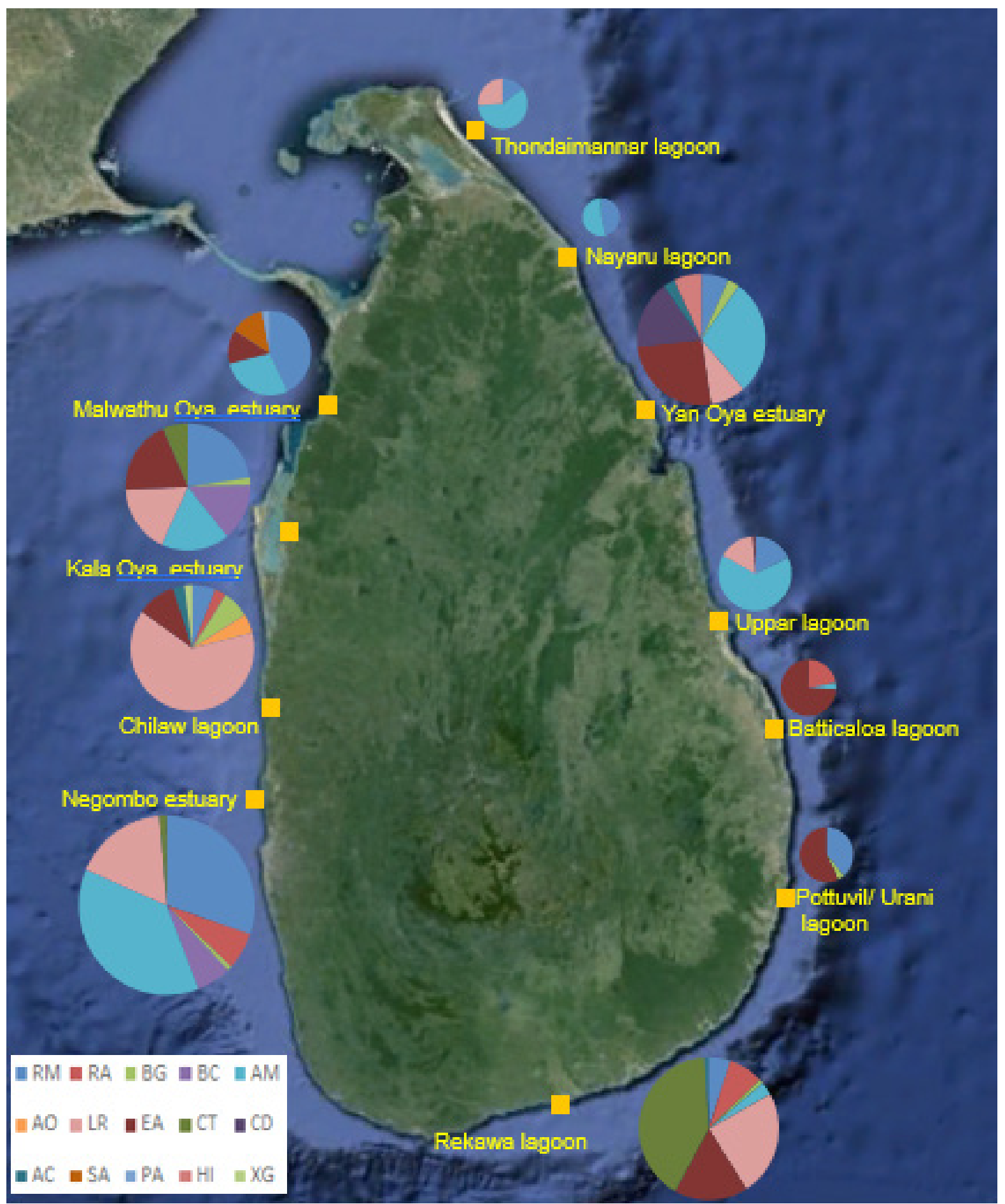

Figure 1: Study areas located eleven (11) estuaries/lagoons around Sri Lanka.

supports the highest number of true mangrove species. Although located on dry coastal areas, the estuaries of Kala Oya on the north western and Yan Oya on the north eastern coasts too support seven species each. These mangrove areas are relatively large in extent and least disturbed. Kala Oya estuary borders the Wilpattu National Park and therefore destructive human interventions are kept minimal. Besides, Kala Oya estuary receives higher volume of irrigation water through the trans-basin Mahaweli river diversion scheme. Yan Oya estuary is situated in an area remote from human settlements and also had not been readily accessible during the recent past due to the unrest that prevailed in the country. Ceriops decandra which was not recorded in the mangrove literature so far, was found to occur only in this estuary.

A major area that had not been visited sufficiently on the east coast is the mangrove stands around Thambalagamuwa bay which is a part of the estuary of Mahaweli river. A preliminary visit to the landward edge of the area revealed the presence of Excoecaria indica (Sapium indicum), a species that was not 
encountered in any of the other mangrove areas visited during the study. However, Jayatissa et al. (2002a) report its occurrence in Bentota and Gin ganga estuaries in the wet zone.

Mangroves on the western and south-western coasts are mostly remnants of larger mangrove areas which have largely been converted to built-up land utilized for coconut and other crop cultivations, homesteads, roads, tourist resorts, hotels and urban utility areas. The number of species that occurs in these relatively small and isolated mangrove stands therefore is low. Nevertheless, Lumnitzera littorea, is found in one such remnant patch associated with the Maduganga estuary (Balapitiya). Occurrence of this species in wet zone estuaries has been first recorded by Abeywickrema (1960). Shrinking mangrove areas through conversion to other land uses may have now confined this species to just one locality in Madu ganga (river), at present. Another rare species among the Sri Lankan mangroves is Scyphiphora hydrophyllacea and it occurs only on the shores of Puttalam lagoon and downstream areas of Kala Oya estuary where the salinity is relatively high. About 18 trees whose leaves, bark and radiating horizontal woody aerial roots resemble those of Xylocarpus moluccensis were found to occur in Dutch bay in proximity to Kala Oya estuary. Pneumatophores however were absent. Since flowers and fruits were also absent at the time of visits, its identification needs further confirmation. Although Sonneratia alba is considered a rare species in Sri Lankan mangrove areas (Jayatissa et al., 2002a), it dominates the Malwathu Oya estuary and comprises some trees with stems larger than $150 \mathrm{~cm}$ in girth at breast height. This is the first record of its occurrence in this estuary. Similarly, the presence of $S$. alba on the west coast of Madagascar (Rasofolo, 1997) could be suspected as evidence for existence of this species on the coasts of the Tethys Sea in Gondwana, before the Indian landmass separated from it. Except for the rare mangrove species that are restricted to very small areas, Nypa fruticans was exclusive to the upstream areas of estuaries in the wet zone where the water salinities are less than $10 \mathrm{mg} \mathrm{l}^{-1}$.

The west coast that spreads through the wet (larger proportion), intermediate and dry climatic zones support the highest number of true mangroves. Relatively low soil salinities and availability of higher allochthonous nutrient and sediment loads from major rivers that discharge large volumes of water annually, may contribute to occurrence of more potential areas/habitats for mangrove colonization and growth on this coast. The low tidal amplitude in the sea around Sri Lanka and coastal geomorphology however restricts the inter-tidal zone into narrow strips, sometimes less than $10 \mathrm{~m}$, except in the estuaries where low terrain permits greater inundation. Although part of the southern coast is located within the wet zone, most of the areas are small remnants of once large mangrove areas and they continue to lose species due to human pressure.

The arid northern coast which does not have estuaries, records the least number of species. The east coast on the contrary, provides more suitable habitats for mangroves, especially in the estuaries of the perennial Mahaweli river and Yan Oya along with a number of seasonal rivers that drain into the ocean creating estuarine habitats conducive for mangrove colonization.

The landward fringe has the most variable floristic composition in most mangrove areas in Sri Lanka which show an abrupt transition from mangrove to terrestrial habitats and this transition depends on the climate and vegetation of the adjacent terrestrial vegetation. In arid coastal areas in the extreme north western, northern and south eastern parts of Sri Lanka, mangroves are associated with hyper-saline salt marshes occupied only by five species of halophytes and salt flats devoid of any vegetation due to extremely high soil salinities. Occasionally, dwarf A. marina occurs in the seaward margin of salt marshes. Mangrove areas in the wet climatic zone in the south western and southern coasts however, have a lower salt concentration in soil towards the landward side, and terrestrial tree species intermingle with mangrove species in this transition zone. Thus, wetter conditions tend to be more hospitable to a wider variety of terrestrial plant species to migrate into the inter-tidal zone.

\section{Potential climatic and anthropogenic influences on the biogeography of mangrove plant species along the coastal areas of Sri Lanka}

Distribution of mangrove species in the three climatic zones does not show a distinct pattern except for $N$. fruticans that is confined to the wet zone, and the rare species which happen to occur in specific areas, both in the wet and dry zones. The relative abundance of mangrove species however reflects availability of habitats under favourable conditions and efficacy of seed/ propagule dispersal. Quantitative data gathered from the mangrove stands on density, basal area and height revealed that on average, A. marina is the most abundant and comprises more than $1 / 3$ of the mangrove stands in Sri Lanka. Low presence of $A$. marina in the intermediate zone however is noteworthy (Figure 2). Lagoons with very high salinities as in the Uppar lagoon on the east coast, are dominated by $A$. marina with scattered $R$. mucronata at the water-front. These two species are the major constituents in Viduthalathivu mangrove area near Mannar as well. Although A. marina was not encountered in the transects laid at Pambala (southern part of Chilaw lagoon that is located in the intermediate climatic zone) in the present study, it is present in the northern sector of the lagoon which is more saline. Though A. marina can tolerate very high soil salinity levels, its absence in low saline areas as in Pambala and Urani/Pottuvil lagoon complex testifies $A$. marina's inability to survive under low salinity levels. Both these mangrove areas are exposed to brackish waters with very low salinity and $A$. officinalis was found instead in very low densities. The second most abundant species encountered in the mangroves of the dry zone is $R$. mucronata followed by L. racemosa and E. agallocha (although not considered as a true mangrove but frequently associated with mangrove areas) and these species occur in both wet and dry zones. Rhizophora mucronata was present in all the major mangrove sites studied and particularly in the Negombo estuary where it was very common. Its abundance in Negombo is partly 
due to cultivation of this species by fishermen to obtain twigs and branches to construct brush parks, a traditional fishing method adopted in this estuary (Amarasinghe, 1988; Amarasinghe et al., 2002). Rhizophora mucronata is planted as erosion barriers to protect homesteads established close to the shoreline of the estuary (Amarasinghe, 1988) and also it is the most preferred species (for the ease of seedling raring) used in mangrove replanting programmes in Sri Lanka (personal observation). Such anthropogenic activities that promote selective propagation of desired species, may become a significant factor that can directly influence the biogeography of species. Avicennia marina and $R$. mucronata frequently form mono-specific stands and when they occur together, more often, the latter occupies the water-front zone and A. marina the landward zone. Lumnitzera racemosa too was recorded in all the mangrove areas; the most luxuriant growth of this species was observed in the Kala Oya estuary and Chilaw lagoon at Pambala. R. apiculata on the contrary, grow well in less saline areas as exemplified by the natural mangrove stands in the Negombo estuary, particularly in those stands associated with Dandugam oya and also in most of the remnant patches of mangroves on the southwestern coast, notably in Bentota, Madu ganga estuary and Galle (Magalla) along with B. gymnorrhiza and S. caseolaris, where salinity is low (personal observations). Rhizophora apiculata forms monospecific stands on the western shores of the Batticaloa lagoon (landward shoreline of the lagoon), where the salinity is as low as $5 \mathrm{mg} \mathrm{l}^{\mathrm{l}^{-1}}$. This species however is absent in the Urani and Pottuvil lagoons on the east coast that are currently exposed to low salinity conditions, suggesting that the salinity change in these lagoons may be a recent phenomenon. Absence of established seedlings and saplings of $R$. mucronata in these mangrove areas may also indicate prolonged freshwater conditions prevailing in these mangrove areas that do not favour the establishment of mangrove seedlings. Anecdotal information however, from communities in the vicinity indicate that in the aftermath of the 2004 Indian Ocean tsunami, sand bar formation at the Pottuvil lagoon entrance to the ocean takes place more frequently than before blocking sea water entering the lagoon; thus it's water has become less saline than it was before the tsunami. Ceriops tagal, Bruguiera gymnorrhiza, Heritiera littoralis and A. officinalis are among the less represented species in the mangrove areas included in the present study. Ceriops tagal, however, is abundant in the Rekawa lagoon (Jayatissa et al., 2002a).

Occurrence of the major true mangrove species in Sri Lankan coasts show affinity to the regional patterns of mangrove distribution. Biogeography of these species within Sri Lanka's coasts and the diversity of mangrove stands appear to be governed considerably by the availability of appropriate habitats in which soil salinity is a critical factor. Perera et al. (2013) revealed that soil salinity plays a major role in maintaining species richness of mangrove areas and that the highest species richness was recorded in areas where soil salinity is $8-12 \mathrm{mg} \mathrm{l}^{-1}$ in the Kala Oya estuary.

The biogeography of mangrove species within an island like Sri Lanka therefore appears to be influenced also by local events such as altered salinity regimes due to long term climate changes that govern rainfall regimes and also due to anthropogenic events. These in turn affect the availability of habitats and conditions (such as salinity) for plant growth. Studies on the genetic structural variability of $L$. racemosa among the Sri Lankan populations was reported to be low, suggesting that at present, there is no barrier for gene flow among populations of this species in the different coasts of Sri Lanka (Su et al., 2006). This may be true for the major mangrove species that show a pancoastal distribution in the island. It is appropriate therefore to include action to monitor salinity as well as hydrology of coastal and near-shore waters that affect availability and quality of habitats for coastal biota. The National Adaptation and Action Plans for Climate Change Impacts in Sri Lanka 2016 to 2025 (Climate Change Secretariat, 2015 ) focuses only on action to mitigate impacts of sea level rise, which is only one of the impacts that climate change can bring about. Altered rainfall and evapotranspiration patterns due to climate change, which concomitantly bring about changes in salinity regimes, particularly in estuaries, appear to cause not very obvious, nevertheless, far-reaching consequences in quality of coastal habitats and composition of flora and fauna that constitute the natural resource base on which the livelihoods of most of the coastal dwellers depend on. Although sea level rise may lead to rise in salinity, both in water and associated soils, increasing river runoff due to elevated rainfall may bring about declining salinities. This scenario may further be exacerbated with economic development activities in the upstream areas that can affect river flow and quality of water, and often it may lead to a greater short-term impact than sea level rise that is expected to happen during relatively a long span that allows provision for adaptation. Monitoring and researching changes in rainfall and evapotranspiration patterns in entire river basins on habitat quality and availability in the coastal areas therefore is appropriate to be included in the national action plan.

The strength and patterns of currents associated with coasts naturally facilitate mangrove seed/propagule dispersion and therefore influence mangrove gene flow between populations occupying distant localities. Currents in the Indian Ocean around Sri Lanka are influenced by the effect of water movement caused by monsoonal winds. During the southwest monsoon, the eastward flowing Southwest Monsoon Current (SMC), and during the northeast monsoon the westward flowing Northeast Monsoon Current (NMC) operate in the sea around Sri Lanka (de Vos et al., 2014). Throughout both monsoon periods, these oceanic currents move southwards along both the eastern and western coasts and converge along the island's southern coast. During the SW monsoon, the island deflects the eastward flowing SMC southward, whilst along the eastern coast the southward flow results from the Sri Lanka Dome. The Sri Lanka Dome (SLD) is an upwelling recirculation feature found in the Southwest Monsoon Current that may significantly influence both biological productivity and air-sea interactions in the Bay of Bengal (de Vos et al., 2014). The large-scale oceanic currents around Sri Lanka therefore undergo complete seasonal reversals. 


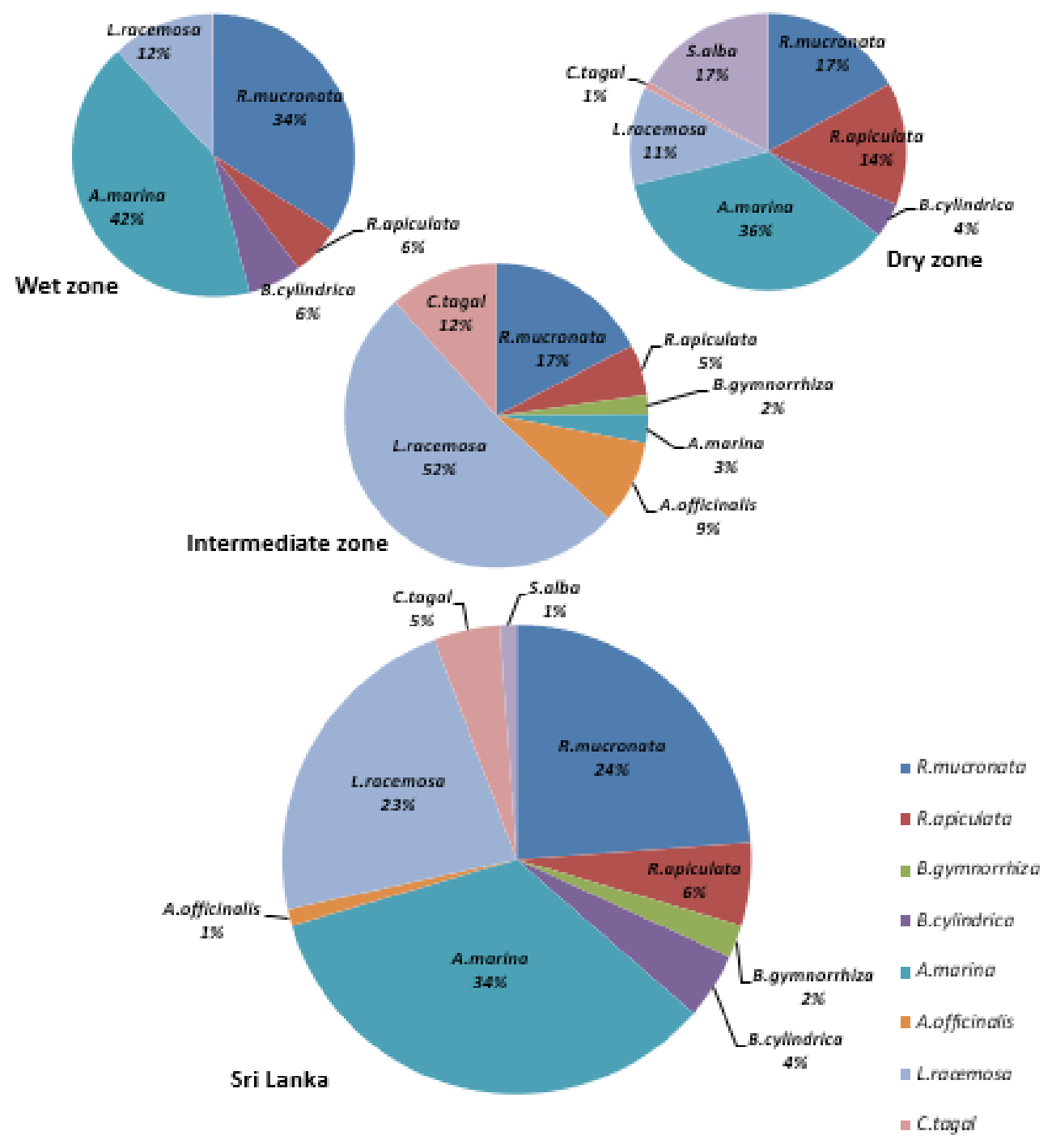

Figure 2: Distribution of mangrove species among different climatic zones of Sri Lanka.

Currents to the east of the island are strongest during the north-east monsoon (November-March), and they change from a clockwise to an anti-clockwise direction and then back again to a clockwise direction during the course of the year. Currents to the south of the island flow eastwards from about May to about October, and westwards for the remainder of the year. In general, the currents off the east coast are stronger than those off the west coast, while those off the southern coast are among the strongest of all, with velocities of around $1 \mathrm{~m} / \mathrm{sec}$ (De Bruin et al., 1994). As such, the flow of ocean water from the western coast of Sri Lanka may not reach the east coast due to the interaction of the southwest monsoon current and the landmass of the island, and therefore can serve as a barrier to gene flow. This too, may contribute to biogeography of species such as Nypa fruticans, distribution of which is confined to the western coast of Sri Lanka.

Besides, the strength and frequency of tidal currents too play a role in dispersing seeds/seedlings within mangrove areas. Tides around Sri Lanka are mixed semi-diurnal with a spring tidal range of between 0.40 and $0.60 \mathrm{~m}$. The range is less in the northern part of the island. The east coast features different phases from the west coast with a rapid change in the southeast (Wijeratne, 2007). The seas around Sri Lanka are micro-tidal and predominantly semidiurnal. The rise and fall of the tides is within $0.7 \mathrm{~m}$ at spring tides and $0.05 \mathrm{~m}$ at neap tides. The highest tidal range is generally around Colombo (west coast), while the lowest is around Delft and Trincomalee (east coast). The small tidal range leads to very low rise in water level in most estuaries, thus causing sand and mud bank formation at the estuary/lagoon mouth blocking their connection to the sea and transforming the estuaries/ lagoons into nearfreshwater bodies (De Bruin et al., 1994). These processes may be further exacerbated with rising sea levels and changing current patterns and therefore will influence the biogeography of both mangrove flora and fauna.

Being adapted to live in the harsh inter-tidal zone, mangroves have been able to survive through times of harsh climate due to their high resilience or resistance (Alongi, 2015). Climatic events that affect mangrove habitats and also the functioning of mangrove plants therefore may affect their biogeography. Mangroves are most vulnerable to climate change, particularly because of their specialty to 
live in the land-sea interface that is susceptible to impacts of changes in sea level which in turn lead to tidal inundation patterns, rainfall and freshwater inputs that affect water and soil salinity conditions which have greater influence on ecosystem functioning. The number of rainy days in Sri Lanka, during the half century period from 1961 - 2012 has decreased while the $2000 \mathrm{~mm}$ isohyet, demarcating the wet zone of the country has shrunk. Water volume by watershed reveals that the watersheds in the northern half of the island have shown an increasing trend in volume of water discharged to the sea while those in the southern half of the island had been decreasing (Manawadu and Fernando, 2008). Since Mangrove taxa are specialized and segregated with respect to tidal height, water salinity, range of salinity of the soil, and soil aeration, the change in freshwater discharge may affect the survival and distribution of mangrove species by altered salinity regimes in the water and soils of the inter-tidal zones (Duke, 1992; Macnae, 1968). On the south eastern coastal belt, Pottuvil and Urani lagoons manifest the impact of decreasing water salinity due to prolonged inundation by increasing freshwater inflow to the lagoon and due to formation of the sand bar at the lagoon mouth severing its connection to the Indian Ocean. Remarkably, Avicennia marina is absent in this lagoon complex, nevertheless, two large (old) Avicennia officinalis trees were observed on the lagoon shoreline closer to the ocean. A similar scenario was observed in the mangrove stand on the southern shoreline of Chilaw lagoon (west coast) where the salinity of water is very low.

Mangroves are subjected to severe human pressure all over the tropics. Mangrove plants are destroyed either directly, or subjected to degradation indirectly due to anthropogenic alteration of habitat conditions such as soil salinity, water salinity, $\mathrm{pH}$, temperature and availability of nutrients. Mangrove areas have extensively been converted to shrimp farms throughout the tropics and Sri Lanka is no exception. Cynometra iripa deserves to be considered either as a very rare or a near-extinct mangrove species in Sri Lanka as mangrove areas of Mi Oya where it was observed to occur in very small numbers, are irreversibly converted into shrimp ponds. The Mi Oya estuary, on the north western coast associated with Puttalam lagoon is extensively destroyed for shrimp culture. This is one of the isolated localities from which Cynometra iripa was recorded (Amarasinghe and Balasubramaniam, 1992).

With release of freshwater from the Uda Walawe irrigation scheme to Kalametiya lagoon, situated on the southern coast of Sri Lanka Sonneratia caseolaris has been found to extend over $30 \%$ more into the intertidal area around the lagoon, than the area covered in 1960 (Jayatissa et al., 2002b). Moreover, the prolonged low salinity in the lagoon waters in 1967, with commencement of the irrigation works in the upstream has replaced the estuarine flora and fauna with freshwater species resulting in total collapse of lagoon fishery, based on prawns and other marine organisms.

The predicted climate change scenario could be expected to variably affect mangroves in different regions. Increasing atmospheric and sea surface temperature would drive mangroves to colonize higher latitudes than at present. Besides, subsidence of low-lying coastal areas such as estuaries, lagoons and islands may cause migration of species into more hinterland. In a micro-tidal environment like in Sri Lanka such expansion will not be possible along the populous southern, south western and western coasts such as Negombo estuary where the hinterland is heavily developed and utilized for other land uses, affecting the biogeography of mangrove species.

\section{REFERENCES}

Abeywickrema, B. A, (1960). Estuarine vegetation of Ceylon. Proc. Abidj. Symp. Humid Trop. UNESCO Paris Fr. 207-210.

Alongi, D.M., (2015). The impact of climate change on mangrove forests. Curr. Clim. Change Rep. 1: 30-39. doi:10.1007/s40641-015-0002-x

Amarasinghe, M.D., (1988). Socio-econo.mic status of human communities of selected mangrove areas on the west coast of Sri Lanka. UNESCO Occ. Pap. 03.

Amarasinghe, M.D. and Balasubramaniam, S., (1992). Structural properties of two types of mangrove stands on the northwestern coast of Sri Lanka. Hydrobiologia 247: 17-27. doi:10.1007/BF00008201.

Amarasinghe, U.S., Amarasinghe, M.D., Nissanka, C., (2002). Investigation of the Negombo estuary (Sri Lanka) brush park fishery, with an emphasis on community-based management. Fish. Manag. Ecol. 9: 41-56. doi:10.1046/j.1365-2400.2002.00250.x.

Climate Change Secretariat, 2015. National Adaptation Plan for Climate Change Impacts in Sri Lanka 2016 to 2025. Ministry of Mahaweli Development and Environment, Sri Lanka.

de Bruin, G.H.P., Russell, B.C., Bogusch, A., (1994). The marine fishery resources of Sri Lanka, FAO species identification field guide for fishery purposes. Food and Agriculture Organization of the United Nations, Rome. 3-4.

de Vos, A., Pattiaratchi, C.B., Wijeratne, E.M.S., (2014). Surface circulation and upwelling patterns around Sri Lanka. Biogeosciences 11: 5909-5930. doi:10.5194/bg11-5909-2014.

Duke, N.C., 1992. Mangrove Floristics and Biogeography. In: Robertson, A.I., Alongi, D.M. (eds.). Tropical Mangrove Ecosystems. American Geophysical Union, pp. 63-100.

Jayatissa, L.P., Dahdouh-Guebas, F. Koedam, N., (2002a). A review of the floral composition and distribution of mangroves in Sri Lanka. Bot. J. Linn. Soc. 138: 29-43.

Jayatissa, L.P., Guero, M.-C., Hettiarachchi, S., Koedam, N., (2002b). Changes in vegetation cover and socioeconomic transitions in a coastal lagoon (Kalametiya, Sri Lanka), as observed by teledetection and ground truthing, can be attributed to an upstream irrigation scheme. Environ. Dev. Sustain. 4: 167-183. doi:10.1023/A:1020831416827

Manawadu, L. and Fernando, N. (2008). Climate change in Sri Lanka. Review Journal of Uni. Colombo 1(2): 126. Macnae, W., (1969). A general account of the fauna and 
flora of mangrove swamps and forests in the Indo-WestPacific Region. Advances in Marine Biology. Elsevier, pp. 73-270.

Monge-Najera, J. (2008). Ecological biogeography: a review with emphasis on conservation and the neutral model. Gayana, 72(1): 102 - 112.

Perera, K.A.R.S., Amarasinghe, M.D. and Somaratne, S. (2013). Vegetation structure and species distribution of mangroves along a soil salinity gradient in a micro-tidal estuary on the northwest coast of Sri Lanka. American J. Marine Sci., 1(1): 7-15.

Rasofolo, M.V.(1997). Use of mangroves by traditional fishermen in Madagascar. Nat. Hist.

Madag. 1: 243-253.
Su, G.-H., Huang, Y.-L., Tan, F.-X., Ni, X.-W., Tang, T., Shi, S.-H., (2006). Genetic variation in Lumnitzera racemosa, a mangrove species from the Indo-West Pacific. Aquat. Bot. 84(4): 341-346.

Wang, L., Mu, M., Li, X., Lin, P., Wang, W., 2010. Differentiation between true mangroves and mangrove associates based on leaf traits and salt contents. J. Plant Ecol. rtq008. doi:10.1093/jpe/rtq008.

Wijeratne, E.M.S., 2007. Sri Lanka levelling of tide gauges for improved hydrodynamic modelling of the Palk Strait. J. Nat. Aquat. Resour. Res. Dev. Agency 38: 1624. 